\title{
Stock Markets, Banks, and Economic Growth: Evidence from Latin American Countries
}

\author{
Omar M. Al Nasser ${ }^{1}$ \\ ${ }^{1}$ School of Business Administration, University of Houston-Victoria, Victoria, Texas, USA \\ Correspondence: Omar M. Al Nasser, School of Business Administration, University of Houston-Victoria, \\ Victoria, Texas, USA. Tel: 1-281-275-8877. E-mail: alnassero@uhv.edu
}

Received: November 17, 2014

Accepted: November 26, 2014

Online Published: January 25, 2015

doi:10.5539/ijef.v7n2p100

URL: http://dx.doi.org/10.5539/ijef.v7n2p100

\begin{abstract}
Utilizing panel data methods and applying Granger causality tests within a framework of a panel cointegration and error correction model, this paper investigates the relationship between financial development and economic growth for 14 Latin American countries from 1978 to 2011. The empirical results show that when banking sector development indicators are used as proxies for financial development, there is evidence of unidirectional causality from economic growth to banking sector development. On the other hand, when stock market development indicators are used as proxies for financial development, the empirical results show that there is a bi-directional causality between stock market development and economic growth.
\end{abstract}

Keywords: financial development, economic growth, Latin America, panel cointegration, panel granger-causality

\section{Introduction}

Economic growth has been the ultimate goal of most, if not all, economies and has been the primary focus of a vast number of economic studies. Several factors are identified as potential determinants in ascertaining economic growth. Among these factors, the impact of financial systems on the economic growth process has received substantial attention in the literature. However, the question still arises with respect to the relationships among financial market development and real economic variables.

The debate has traditionally revolved around two issues. The first issue is whether financial development results in faster economic growth; while the second one is to how financial development affects economic growth. Although several theoretical and empirical studies have emerged to answer the above questions, no clear consensus has been reached on either issue.

Relative to the first issue, two opposing views have emerged from the theoretical literature. Some studies argue that financial development is an essential element in promoting economic growth. They emphasize that the limited resources will be channeled from the surplus units to deficit units with the existence of a well-developed financial sector. This will lead to higher economic growth as a result of increasing the size of savings and improving the efficiency of investment. Contrarily, there are those who argue that when an economy grows, more financial products will be available in the markets in response to higher demand. According to this perspective, financial development simply follows economic growth.

Previous studies on the relationship between financial development and economic growth have concentrated primarily on a broad cross-section of countries, with little work on the correlation between financial market development and economic growth in Latin America. The purpose of this paper is to investigate the short and the long-run relationship between financial development and economic growth in 14 Latin American countries from 1978 to 2011. Specifically, what role does the financial sector play in the economic growth process? What effect, positive, negative or zero, has financial development exerted on economic growth? What type of causality exists in the finance-growth nexus?

Utilizing panel data methods and applying Granger causality tests within a framework of a panel cointegration and error correction model, this paper attempts to answer these questions empirically and shed some light on the roles of financial development as well as other conditional variables in determination of economic growth. Pooling only Latin American countries in the analysis is appropriate because empirical evidence has shown that 
financial development has varying effects on economic growth in countries with different income levels and different levels of financial development.

This study could be instructive and complementary to the existing literature in several distinct ways. First, although the existence of a relationship between financial development and economic growth is now widely recognized, the theoretical models and empirical analyses have not reached an agreement with regard to this relationship. The results offer conflicting predictions about the direction of causality and the separate role of banks and stock markets in achieving higher economic growth.

Second, we distinguish between the short-run and the long-run causality relationship between financial development and economic growth. Darrat (1999) argues that most of the financial development's benefits are realized in the short-run, while these effects slowly disappear in the long-run as the economy grows. Thus, testing only for the short-run causality would lead to the wrong conclusion, namely absence of any causal relationship between financial development and economic growth in the long-run. To this end, we use the Granger-causality test within an error correction model to examine the causality between financial development and economic growth. Finally, we use six different measures of financial development to test the robustness of our results.

The remainder of the paper is organized as follows. Section 2 reviews the literature on financial development and economic growth. Section 3 describes data sources and variable definitions. Section 4 outlines model specification and estimation methodology. Section 5 discusses the main empirical results; and Section 6 summarizes the major findings and offers some policy implications. Data definitions and sources are provided in Table 1.

Table 1. Definition of variables

\begin{tabular}{lll}
\hline \multicolumn{1}{c}{ Variable } & \multicolumn{1}{c}{ Definition } & Source \\
\hline Growth of real per capita GDP & Annual growth of per capita real GDP & WDI \\
Stock Market Capitalization & Total market value of all listed shares / GDP & FSEDD \\
Stock Market Turnover Ratio & Value of trades of shares over market capitalization & FSEDD \\
Stock Market Value Traded & Value of trades of domestic stocks / GDP & FSEDD \\
Private Credit & Private Credit by Deposit Banks and Other Fin.Inst / GDP & FSEDD \\
Liquid Liabilities & Liquid Liabilities / GDP & FSEDD \\
Bank Assets & Deposit Money Bank Assets / GDP & FSEDD \\
Government Consumption & Government final consumption expenditure / GDP & WDI \\
Inflation & Percentage change of the Consumer Price Index (CPI) & WDI \\
Openness & Total amount of exports and imports / GDP & WDI \\
School Enrollment & Secondary school enrollment rate & WDI \\
\hline
\end{tabular}

Note. The dataset used in this study are obtained from Financial Structure and Economic Development Database and the World Development Indicator published by the World Bank.

\section{The Finance-Growth Link}

Theoretical models, in general, assume that financial development affects economic growth via two channels. First, financial development could lead to higher savings rate and thus could increase the available financial resources to finance investment opportunities. Second, financial development results in efficient allocation of savings, hence enhancing the productivity of investment. McKinnon (1973) and Shaw (1973) argue that a major role of financial systems is saving mobilization. By increasing the size of savings, financial systems channel a larger fraction of savings to finance a greater number of innovative projects. This increases the technological innovation and economic growth.

A large body of literature exists that examines the role of financial development as a growth-enhancing factor (Note 1). However, one question has remained unanswered in the literature is whether the policymakers should first pursue financial development or economic growth, or whether they should pursue both financial development and economic growth concurrently. In other words, there is a debate on the causal relationship between financial development and economic growth that has both theoretical and policy implications.

From a theoretical perspective, economists hold different views on the relationship between financial development and economic growth. The first is the "supply-leading" view advanced by Schumpeter (1911). He 
argues that both savings and investment rates will raise as a well-developed financial sector channels the limited resources from surplus units to deficit units. The supply-leading view has received considerable attention and support from recent empirical studies (King \& Levine, 1993; Rousseau \& Wachtel, 2002; Hondroyiannis, Lolos, \& Papapetrou, 2004; Deb \& Mukherjee, 2008).

The second view, "demand-pulling" proposed by Robinson (1952), conversely argues that financial development follows economic growth. According to this phenomenon, more financial products emerge in the markets in response to higher demand of financial services as the economy grows, thereby leading to financial development. Studies by Ang and McKibbin (2007), Shan, Sun and Morris (2001), and Claessens and Laeven (2003) are consistent with the demand-pulling view.

Third, the "feedback" view suggests a two-way causality between financial market development and economic growth. It states that a country with a well-developed financial system could promote economic growth through technological changes and product and service innovations. This, in turn, will create high demand for financial products and services (Levine, 1997; Ikikii \& Nzomoi, 2013). As banking institutions effectively respond to the increasing demand, then these changes will achieve greater economic growth. Therefore, both financial market development and economic growth are positively interdependent, and their relationship could lead to feedback causality. Studies by Demetrides and Hussein (1996), Luintel and Khan (1999), Hondroyiannis et al., (2004), Al-Yousif (2002), Deb and Mukherjee (2008), and Padhan (2007) are supportive of this view. Finally, Lucas (1988) put forward the fourth view of the relationship between the two variables, which argues that there is no causality between financial development and economic growth. He argues that studies overstressed the role of financial development in the economic growth process.

In recent years, investigations have given rise to the interest on the relationship between financial development and economic growth (King \& Levine, 1993; Levine \& Zervos, 1998; Beck \& Levine, 2004; Okoye \& Nwisienyi, 2013). Although several theoretical and empirical studies have devoted considerable attention to the relationship between financial development and economic growth, the results are inconclusive in regard to the impact of financial development on growth and the separate effects of stock markets and banks on economic growth. King and Levine (1993) examine the effect of financial development on economic growth in a sample of more than 80 countries. To test this relationship, King and Levine construct several financial ratios, which proxy for specific characteristics of the financial sector. The results show that the size of the financial sector relative to GDP has a significant effect on economic growth.

Rousseau and Wachtel (2000) and Beck and Levine (2004) extend the Levine and Zervos (1998) approach of stock markets, banks, and growth by using GMM techniques. Rousseau and Wachtel (2000) use annual data and the difference estimator. Beck and Levine (2004) use data averaged over five-year periods and the system estimator to reduce potential biases related to the difference estimator, and extend the sample through 1998. Both studies are in line with supply-leading views that stressed the important role of financial development on economic growth. In addition, the empirical evidence provides conflicting predictions about whether stock markets and banks are substitutes or complements, and whether bank-based or market-based financial systems are better for promoting long-run economic growth. Using a broad cross-country dataset, Levine (2002) examines the bank-based and market-based views and long-run economic growth. The empirical results show no evidence for the bank-based or market-based views.

The debate on determining what comes first, financial development or economic growth, is far from resolution. Finding the direction of causation between financial development and economic growth is relevant for Latin American countries since they have undergone significant reforms in the financial sector, and it is necessary to determine whether further reforms to this sector are conducive to economic growth.

\section{Data Description}

This section provides a brief description of the variables used in this study. We investigate the short-run and the long-run relationship between financial development and economic growth in 14 Latin American countries from 1978 to 2011 (Note 2). Following standard practice, we use the growth of real per capita GDP as our measure of economic growth (EG). In addition, we use six different measures of financial development to test the robustness of our results.

We follow King and Levine (1993) and Boyd et al. (2001), and employ three proxies to measure banking sector development. The first measure is the ratio of liquid liabilities (LIQ) of the financial sector to GDP. This indicator measures the size of the banking sector in relation to the economy as a whole and has been found to be strongly associated to the real GDP per capita. As noted by King and Levine (1993), this measure may not be closely related to other financial services such as risk management and information processing. Consequently, 
our second measure is bank assets (BA), which equals the ratio of total assets of deposit money banks as a percentage of GDP.

Since the above two measures do not consider the allocation of capital between the private and public sector and in order to obtain a more direct measure of financial depth, we use the private credit (PC) as our third measure of banking sector development. In order to capture the relative size and the level of development of the stock market, the first measure is total stock market capitalization as a percentage of GDP (SMC). This measure is computed as the average value of listed domestic shares on domestic exchanges in a year as a share of the size of the economy. Studies frequently use SMC as an indicator of stock market development (Levine \& Zervos, 1998; Andres, Hernando, \& Lopez-Salido, 1999; Boyd et al., 2001).

The second and third measures of stock market development are frequently used in the literature as indicators of market liquidity. Value traded (VT) equals the value of the trades of domestic shares on domestic exchanges divided by GDP. VT measures trading volume as a share of national output and should therefore positively reflect liquidity on an economy wide basis. Turnover ratio (TR) equals the value of the trades of domestic shares on domestic exchanges divided by the value of listed domestic shares. Thus, TR measures trading volume relative to the size of the market. This ratio complements the SMC. A large but inactive market will have a large market capitalization ratio, but a small turnover ratio (Boyd, Levine, \& Smith, 2001). TR also complements the total VT since value traded captures trading relative to the size of the economy and TR measures trading relative to the size of the market (Garcia \& Liu, 1999). Consequently, a small liquid market will have high turnover, but small value traded.

We regress each of our measures of stock market and bank development on economic growth, plus a set of variables in order to control for other potential determinants of economic growth. In the simple control variables set, we include the logarithm of the secondary school enrollment $(\mathrm{SCH})$, measured by the proportion of the population of the age group who officially corresponds to the duration of general secondary schooling, to control for the level of human capital. We expect the coefficient on SCH to be positive (Abramovitz, 1986). In addition, we use the ratio of exports plus imports to GDP (OP) to capture the degree of openness of an economy. A large body of studies has found positive and significant effects of OP on economic growth (Tyler, 1981; Moschos, 1989; Levine et al., 2000; Apergis et al., 2007).

Additional conditioning variables include the ratio of government expenditure to GDP (GOV) and inflation rate (IR) as indicators of macroeconomic stability. Empirical studies produce mixed evidence regarding the impact of GOV on the long-run economic growth. Some studies suggest that GOV has a significant positive role in determining the level of economic growth (Tang, 2006; Aslan, 2008). Further, other studies suggest a negative relationship between the two variables (Fischer, 1993; Easterly \& Rebelo, 1993; Bruno \& Easterly, 1998). More specifically, as Barro and Sala-i-Martin (1995) point out, the GOV variable is intended to capture public expenditures that do not directly affect productivity, but will entail distortions on private decisions. However, the mixed evidence regarding the impact of GOV economic growth differ by country, method employed, and the form of public expenditure (i.e., productive and unproductive expenditure). Thus, the coefficient associated to this variable is not determined a priori.

IR is measured by the percentage change in the consumer price index (CPI). The relationship between inflation and economic growth is found in the literature to be negative and significant, especially in the cases of high inflation (Fischer, 1993; Barro, 1996; Bruno \& Easterly, 1998). A negative relationship is expected between IR and economic growth.

\section{The Model and Estimation Methodology}

\subsection{Panel Data Methodology}

In order to analyze the link between financial development and economic growth in Latin American countries, we use panel data methodology. The use of panel data in the analysis allows us to measure how the change in financial development over time may affect economic growth among Latin American countries. Furthermore, panel data estimation techniques, in this context, offer some advantages over cross-section or time series.

In this paper, a specific set of countries is being investigated, i.e., Latin American countries. Inference in this case is conditional on the particular countries that are observed. In pooled cross-country and time-series data, unobservable fixed effects may be correlated with the included explanatory variables to create omitted variable biases. To correct them, we employ panel estimation with country-specific fixed effects. The fixed-effects model is therefore the most appropriate specification. Specifically, we estimate: 


$$
E G_{i t}=\alpha_{i}+\beta F D_{i t}+Z_{i t}+\varepsilon_{i t}, \quad i=1, \ldots, n, \quad t=1, \ldots, T_{i}
$$

where the subscript $i$ represents Latin American countries and subscript $t$ represents time. $E G_{i t}$ is the level of economic development, measured by the growth of real per capita GDP in the $i$ th country for the time-period, which is our measure of economic growth. $F D_{i t}$ denotes the measures of financial development, which includes measures of stock markets and banking sector development variables. $Z_{i t}$ represents a set of variables that controls for other factors associated with economic growth. The error term is $\varepsilon_{i t}$.

\subsection{Panel Cointegration Tests}

The concept of cointegration was first introduced into the literature by Granger (1980). The principle of testing for cointegration is to test whether two or more integrated variables deviate significantly from a certain relationship. In other words, if the variables are cointegrated, they move together over time so that short-run disturbances will be corrected in the long-run.

Traditional tests of cointegration include the simple two-step test by Engle and Granger (1987) and Johansen (1988). Although these tests have commonly employed in the literature to test for the long-run relationship among a set of variables, both tests are useful in conducting individual cointegration tests, but do not address cointegration tests in panel settings, thus suffering from severe size distortion when applied.

To overcome these problems, the next step of our empirical work is to apply panel cointegration methodology to investigate the long-run relationship between financial development and economic growth. Following the methodology employed by Pedroni (1999), the cointegration relationship we estimate is specified as follows:

$$
E G_{i t}=\alpha_{i}+\delta_{i} t+\beta_{i} F D_{i t}+\varepsilon_{i t}, \quad i=1, \ldots, N, \quad t=1, \ldots, T
$$

where the subscript $i$ represents country $i$ and subscript $t$ represents time. $E G$ is the growth of real per capita GDP and $F D$ denotes the measure of financial development. $\alpha_{i}$ is the country-specific effect, $\delta_{i} t$ is the deterministic time trend, and $\varepsilon_{i, t}$ are the estimated residuals (Note 3 ).

\subsection{Panel Granger Causality Tests}

If $E G$ and $F D$ are cointegrated, this implies a long-run linear relationship between the two variables. However, although cointegration indicates the presence or the absence of Granger-causality, it does not indicate the direction of causality between the variables. Our final step consists of investigating the direction of causation between financial development and economic growth using the Granger-causality test within an error correction model (ECM).

The standard Granger causality test measures the ability of a variable $F D$ to explain the current value of another variable $E G$. Furthermore, $E G$ is said to be Granger-caused by $F D$ if $E G$ can be predicted better from the past values of both $E G$ and $F D$ than from the past values of $E G$ alone. In other words, the lagged values of $F D$ are statistically significant. In order to test if $E G$ is Granger-caused by $F D$, we specify the $E G$ function as follows:

$$
\begin{aligned}
& E G_{t}= a_{0}+\sum_{j=1}^{p} a_{1 i} E D_{t-j}+\sum_{j=1}^{p} a_{2 i} F D_{t-j}+u_{t} \\
& H_{0}: a_{2 i}=0 \quad \text { for } \quad j=1, \ldots, p \\
& H_{1}: a_{2 i} \neq 0 \quad \text { for at least one } j,
\end{aligned}
$$

where $a_{0}$ is a constant, $u_{t}$ is a white noise error process, and $p$ is the number of lagged variables. $F D$ is said to Granger-cause variable $E G$ if we reject the null hypothesis in (4), where $a_{2 \mathrm{i}}$ is the vector of the coefficients of the lagged values of $F D$. Similarly, we test if $E G$ is Granger-caused by $F D$ as follows:

$$
\begin{gathered}
F D_{t}=b_{0}+\sum_{j=1}^{p} b_{1 i} F D_{t-j}+\sum_{j=1}^{p} b_{2 i} E D_{t-j}+v_{t} \\
H_{0}: b_{2 i}=0 \quad \text { for } \quad j=1, \ldots, p \\
H_{1}: b_{2 i} \neq 0 \quad \text { for at least one } j,
\end{gathered}
$$

where $b_{0}$ is a constant and $v_{t}$ is a white noise error process. $E G$ is said to Granger-cause variable $F D$ if we reject the null hypothesis in (6) where $b_{2 \mathrm{i}}$ is the vector of the coefficients of the lagged values of $E G$.

According to Engle and Granger (1987), one problem with the standard Granger causality tests is the possibility 
of finding no causal relationship between two variables that are cointegrated. Hence, if two or more variables are found to be cointegrated, the lagged error-error correction term (ECT), derived from the cointegration equation, must be incorporated into the model to reintroduce the long-run information lost in the differencing process. In general, the ECM is formed by adding an ECT as another regressor to the model with the stationary variables. This term is the lagged-once residuals that are generated from the long-run relationship between the variables in the model. To investigate the causal relationship between financial development and economic growth, we estimate the following bivariate ECM as follows:

$$
\begin{gathered}
\Delta E G_{i t}=\alpha_{0}+\sum_{j=1}^{p} \alpha_{1 i} \Delta E G_{i t-j}+\sum_{j=1}^{p} \alpha_{2 i} \Delta F D_{i t-j}+\alpha_{3} E C T_{t-1}+u_{1 i t} \\
\Delta F D_{i t}=\beta_{0}+\sum_{j=1}^{p} \beta_{1 i} \Delta F D_{i t-j}+\sum_{j=1}^{p} \beta_{2 i} \Delta E G_{i t-j}+\beta_{3} E C T_{t-1}+u_{2 i t}
\end{gathered}
$$

where $\Delta$ is the difference operator; $p$ denotes the lag length; and $u_{1 \mathrm{t}}$ and $u_{2 \mathrm{t}}$ are white-noise error terms. $E C T_{t-1}$ is one period lagged error correction term derived from the long-run relationship in equation (2). The principle behind this model is that there often exists a long-run equilibrium relationship between two economic variables. In the short-run, however, there may be disequilibrium in response to short-run shocks.

Granger causality implies testing the significance of the hypotheses $H_{0}: \alpha_{2 \mathrm{i}}=0$, and or $\alpha_{3}=0$ and $H_{0}: \beta_{2 \mathrm{i}}=0$, and or $\beta_{3}=0$. From equation (7), we say that $\triangle F D$ Granger causes $\triangle E G$ if $\alpha_{2 i}$ 's and/or $\alpha_{3}$ is statistically significant. Likewise, from equation (8), $\Delta E G$ Granger causes $\Delta F D$ if $\beta_{2 \mathrm{i}}$ 's and/or $\beta_{3}$ is statistically significant. In addition to indicating the direction of causality amongst variables, the ECM enables us to distinguish between the short-run and the long-run causality. The significance of $\alpha_{2 \mathrm{i}}$ and $\beta_{2 \mathrm{i}}$ indicate short-run causality, while the significance of $\alpha_{3}$ and $\beta_{3}$ coefficients indicate long-run causality between the two variables. Hence, movements along this path are considered permanent. The $F$-test of the explanatory variables indicates short-run causal effects, whereas the long-run causal relationship is implied through the significance of the $t$-test of the lagged error-correction term. Of course, if the two variables were not cointegrated, the ECT will not appear in the above equation, in which case we test only for the short-run causality.

If $H_{0}$ in equation (7) is rejected $\left(H_{0}: \alpha_{2 \mathrm{i}}=0, \alpha_{3}=0\right)$, it shows that $F D$ Granger causes $E G$. In this scenario, financial development causes economic growth (supply-leading view). In this situation, a well-developed financial sector proceeds and helps in the development of the economy's real sector through transferring and channeling limited resources to the more productive sectors. Rejection of $H_{0}\left(H_{0}: \beta_{2 \mathrm{i}}=0, \beta_{3}=0\right)$ in equation (8) means that the causality runs from $E G$ to $F D$ as postulated by the demand-pulling view. According to this scenario, when an economy grows, more financial institutions and financial products emerge in the markets in response to higher demand of financial services and thereby leads to financial development.

If none of the null hypotheses are rejected, it means that $F D$ does not Granger cause $E G$ and $E G$ also does not Granger cause $F D$ in both the short-run (i.e. $\alpha_{2 \mathrm{i}}$ 's and $\beta_{2 \mathrm{i}}$ 's) and the long-run $\left(\alpha_{3}\right.$ and $\left.\beta_{3}\right)$. This indicates that the two variables are independent of each other. According to this proposition, financial development and economic growth are caused by other factors that have a role in their development. Finally, if all the null hypotheses are rejected, there is bi-directional causality between financial development and economic growth in both the short-run and the long-run (feedback hypothesis). In this scenario, economic growth causes financial development and financial development causes economic growth. According to this proposition, economic growth stimulates and permits financial development and, in turn, this financial development results in accelerated economic growth.

\section{Empirical Results}

\subsection{Panel Unit Root Results}

The variables of economic growth $(E G)$, measures of financial development ( $L I Q, B A, P C, S M C, V T, T R)$, and all control variables $(G O V, O P, S C H, I R)$ are tested for unit root both in levels and in first differences. The results from the Im, Pesaran, and Shin (2003) unit root (IPS) test are reported in Table 2. The results from the IPS test show that we cannot reject the unit root hypothesis when the variables are in level, but when first differences are used, the hypothesis of unit root is rejected at the $1 \%$ significance level. Therefore, our series is well characterized as an I(1) process (Note 4). These results allow us to test for cointegration among the variables in consideration. 
Table 2. Panel unit root tests

\begin{tabular}{lcc}
\hline & Levels & First differences \\
\hline EG & $\mathbf{- 1 . 4 2 9}$ & $-3.395 * * *$ \\
SMC & $\mathbf{- 1 . 3 6 1}$ & $-5.870 * * *$ \\
TR & $\mathbf{- 2 . 3 1 4}$ & $-9.574 * * *$ \\
VT & $\mathbf{- 1 . 9 0 6}$ & $-8.423 * * *$ \\
PC & $\mathbf{- 1 . 2 0 2}$ & $-3.645 * * *$ \\
LIQ & $\mathbf{- 0 . 8 3 5}$ & $-4.100 * * *$ \\
BA & $\mathbf{0 . 7 4 1}$ & $-6.261 * * *$ \\
GOV & $\mathbf{1 . 1 0 3}$ & $-4.247 * * *$ \\
IR & $\mathbf{- 1 . 7 3 5}$ & $-8.620 * * *$ \\
OP & $\mathbf{- 0 . 7 1 9}$ & $-9.013 * * *$ \\
SCH & $\mathbf{0 . 2 3 2}$ & $-9.792 * * *$ \\
\hline
\end{tabular}

Note. Panel unit root tests are estimated based on Im, Peseran and Shin (2003) test. The Critical Values are $-2.68,-2.53$, and -2.4 at $1 \%, 5 \%$, and $10 \%$ statistical levels, respectively. Boldface values denote sampling evidence in favor of unit roots. ***signifies rejection of the unit root hypothesis at the $1 \%$ level.

\subsection{Panel Cointegration Results}

Having established that economic growth and financial development series are integrated of the first order, the second step is to test for the cointegration relationship between the two variables. To achieve this, as explained earlier, we use the Pedroni panel cointegration test. Tables 3 and 4 report the panel cointegration test results for stock markets and banking sector development measures.

Table 3. Panel cointegration tests (stock market data set)

\begin{tabular}{lccc}
\hline & $\boldsymbol{S M C}$ & $\boldsymbol{V T}$ & $\boldsymbol{T R}$ \\
\hline Panel v-Statistic & $-3.84 * * *$ & $-3.86 * * *$ & $-3.86 * * *$ \\
Panel rho-Statistic & $-9.24 * * *$ & $-8.37 * * *$ & $-8.84 * * *$ \\
Panel PP-Statistic & $-34.25 * * *$ & $-36.67 * * *$ & $-36.05 * * *$ \\
Panel ADF-Statistic & $-19.11 * * *$ & $-19.24 * * *$ & $-17.79 * * *$ \\
Group rho-Statistic & $-6.88^{* * *}$ & $-6.21 * * *$ & $-6.62 * * *$ \\
Group PP-Statistic & $-37.63 * * *$ & $-38.20 * * *$ & $-39.83 * * *$ \\
Group ADF-Statistic & $-20.81 * * *$ & $-19.33^{* * *}$ & $-18.69 * * *$ \\
\hline
\end{tabular}

Note. The cointegration tests were undertaken with different measures of stock market development, indicated by SMC, VT, and TR. The models have been specified with deterministic intercept and trend. ***Signifies rejection of null hypothesis of no cointegration at $1 \%$ level.

Tables 3 and 4 present seven test statistics: (i) v-statistics, (ii) panel rho-statistics, (iii) panel ADF-statistics, (iv) panel PP-statistics, (v) Group rho-statistics, (vi) Group ADF-statistics, and (vii) Group PP-statistics. It can be seen from the test results in both tables that Pedroni's statistics significantly reject the null of no cointegration at $1 \%$ significance level in all cases and for the six indicators of financial development. This implies a long-run co-movement between financial development and economic growth. That is, there is a long-run steady-state relationship between financial development and economic growth for the panel of Latin American countries. Given the variables in Tables 3 and 4 are cointegrated, the long-run relationship can be estimated.

\subsection{Panel Estimation Results}

This study mainly focuses on the effects of two major aspects of financial development on economic growth: stock market and banking sector. The use of panel data in the analysis allows us to measure how the change in financial development over time may affect economic growth among these countries (Levine, Loayza, \& Thorsten, 2000). The fixed effects model is constructed to take into account the country-specific and time effects. 
Table 4. Panel cointegration tests (banking sector data set)

\begin{tabular}{lccc}
\hline & $\boldsymbol{L I Q}$ & $\boldsymbol{B} \boldsymbol{A}$ & $\boldsymbol{P C}$ \\
\hline Panel v-Statistic & $-2.85 * * *$ & $-2.98 * * *$ & $-3.51 * * *$ \\
Panel rho-Statistic & $-8.75 * * *$ & $-9.66 * * *$ & $-9.99 * * *$ \\
Panel PP-Statistic & $-36.05 * * *$ & $-31.51 * * *$ & $-29.15^{* * *}$ \\
Panel ADF-Statistic & $-19.20^{* * *}$ & $-18.62 * * *$ & $-19.84 * * *$ \\
Group rho-Statistic & $-6.76^{* * *}$ & $-7.14 * * *$ & $-7.46 * * *$ \\
Group PP-Statistic & $-37.53 * * *$ & $-34.90 * * *$ & $-32.96 * * *$ \\
Group ADF-Statistic & $-19.91 * * *$ & $-19.65 * * *$ & $-20.77 * * *$ \\
\hline
\end{tabular}

Note. The cointegration tests were undertaken with different measures of banking sector development, indicated by LIQ, BA, and PC. The models have been specified with deterministic intercept and trend. ***Signifies rejection of null hypothesis of no cointegration at $1 \%$ level.

Table 5 provides the estimation results. The benchmark equation omits the financial development indicators. All variables in the benchmark equation have the right sign and are statistically significant. GOV exhibits a statistically significant negative coefficient. This points to a low efficiency of government spending in Latin American countries. Furthermore, a positive impact of $\mathrm{SCH}$ on economic growth is also reported in our estimations, although its coefficient become less insignificant after the entry of VT. The coefficient of OP carries the expected sign and is statistically significant. This implies that openness to trade has stimulated economic growth in Latin America. The results also show that IR has the potential to inhibit economic growth as indicated by a statistically negative coefficient.

The first three columns report the estimation results of the same equation with one of the three banking sector development indicators (BA, LIQ, PC) as an additional explanatory variable. The coefficients of BA are negative and insignificant in all cases, thus proving that there is no enough evidence to reject the null hypothesis of exogenous effect of bank assets on growth. Column (2) shows that financial development, as measured by the LIQ variable, has a positive and significant impact on economic growth. In particular, a $1 \%$ increase in the LIQ increases economic growth by $0.065 \%$. In addition, the coefficients of PC are positive and significant in all regressions, which suggest that an increase in banking credits to the private sector will effectively stimulate economic growth in Latin America.

The last three columns report the estimation results for equation (1) using stock market variables as the proxy for financial development. The coefficients of all three indicators of stock market development (SMC, VT, TR) are positive and significant. When SMC, for example, is used as a proxy for financial development, significantly positive coefficients suggest that the size of stock markets increases the economic growth rate. Alternative measures of stock market development tell the same story. For instance, VT and TR are also good forecasters of economic growth. These two measures of liquidity show that countries with more liquid stock markets tend to grow faster. These results are consistent with Boubakari and Jin (2010).

The estimated coefficients of all control variables are robust with respect to the choice of financial development indicators. In particular, GOV, OP, and IR retain their original signs and remain significant in explaining economic growth. Overall, the results summarized in Table 5 suggest that financial development, measured either by stock markets or by banking sector indicators, had a significant and positive impact on economic growth in Latin America from 1978-2011. These results support previous empirical evidence on the positive relationship between financial development and economic growth (Note 5). Furthermore, the results show that both stock markets and banking sector development indicators enter the growth regression significantly, regardless of the control variables. This indicates that banks and stock markets work together in Latin American countries, implying that a well-functioning stock market enables entrepreneurs to make more productive investments because they have access to longer-term sources of funds (Levine, 1997).

In Table 6, we estimate equation (1) by employing the random effect method, which assumes that the individual effects are uncorrelated with the other regressors in the model. The estimated results are similar to those reported in Table 7 and, consequently, we do not discuss them in detail. The choice between random effects and fixed effects is determined by the Hausman test, which tests for misspecification in the random effects model. At the bottom of Table 6, the Hausman test rejects the null of the random effects for four out of six cases. The rejection of the random effect indicates the appropriate use of fixed-effects in the regressions. 
Table 5. Panel regression results: the impact of financial development on economic growth

\begin{tabular}{|c|c|c|c|c|c|c|c|}
\hline $\begin{array}{c}\text { Independent } \\
\text { Variables }\end{array}$ & Benchmark & 1 & 2 & 3 & 4 & 5 & 6 \\
\hline \multirow[t]{2}{*}{ GOV } & -0.114 & -0.112 & -0.113 & -0.111 & -0.095 & -0.092 & -0.099 \\
\hline & $(-6.042)^{* * *}$ & $(-5.762)^{* * *}$ & $(-5.875)^{* * *}$ & $(-5.415)^{* * *}$ & $(-4.034) * * *$ & $(-3.890)^{* * *}$ & $(-3.977)^{* * *}$ \\
\hline \multirow[t]{2}{*}{$\mathrm{SCH}$} & 0.03 & 0.033 & 0.027 & 0.034 & 0.036 & 0.028 & 0.057 \\
\hline & $(3.61)^{* *}$ & $(3.88)^{* *}$ & $(2.82)^{* *}$ & $(4.09)^{* *}$ & $(3.84)^{* *}$ & $(0.86$ & $(1.67$ \\
\hline \multirow[t]{2}{*}{ OP } & 0.032 & 0.031 & 0.029 & 0.028 & 0.018 & 0.021 & 0.018 \\
\hline & $(5.508)^{* * *}$ & $(5.439)^{* * *}$ & $(4.766)^{* * *}$ & $(4.694)^{* * *}$ & $(1.801)^{*}$ & $(2.071)^{* *}$ & $(5.75)^{* *}$ \\
\hline \multirow[t]{2}{*}{ IR } & -0.076 & -0.084 & -0.047 & -0.040 & -0.084 & -0.095 & -0.078 \\
\hline & $(-4.54)^{* * *}$ & $(-3.29)^{* * *}$ & $(-3.05)^{* * *}$ & $(-2.80)^{* * *}$ & $(-3.29) * * *$ & $(-2.89)^{* * *}$ & $(-4.76)^{* * *}$ \\
\hline \multirow[t]{2}{*}{$\mathrm{BA}$} & & -0.360 & -1.430 & -0.790 & -1.270 & -1.250 & -0.950 \\
\hline & & $(-0.24)$ & $(-0.85)$ & $(-0.48)$ & $(-0.74)$ & $(-0.73)$ & $(-0.50)$ \\
\hline \multirow[t]{2}{*}{ LIQ } & & & 0.065 & 0.021 & 0.014 & 0.019 & 0.018 \\
\hline & & & $(4.19)^{* *}$ & $(4.87)^{* *}$ & $(3.21)^{* *}$ & $(4.24)^{* *}$ & $(3.93)^{* *}$ \\
\hline \multirow[t]{2}{*}{$\mathrm{PC}$} & & & & 0.074 & 0.062 & 0.089 & 0.058 \\
\hline & & & & $(2.39)^{* *}$ & $(1.92)^{*}$ & $(3.32)^{* * *}$ & $(5.84)^{* * *}$ \\
\hline \multirow[t]{2}{*}{ SMC } & & & & & 0.025 & 0.025 & 0.011 \\
\hline & & & & & $(6.10)^{* *}$ & $(5.31)^{* *}$ & $(2.96)^{* *}$ \\
\hline \multirow[t]{2}{*}{ VT } & & & & & & 0.010 & 0.009 \\
\hline & & & & & & $(4.34)^{* *}$ & $(4.01)^{* *}$ \\
\hline \multirow[t]{2}{*}{ TR } & & & & & & 0.020 & 0.012 \\
\hline & & & & & & $(5.19)^{* *}$ & $(3.22)^{* *}$ \\
\hline Adj R-squared & 0.289 & 0.299 & 0.315 & 0.314 & 0.318 & 0.314 & 0.355 \\
\hline Durbin-Watson & 2.062 & 2.220 & 1.842 & 2.041 & 2.019 & 2.150 & 2.236 \\
\hline
\end{tabular}

Note. Values in parentheses are t-statistics. *Significant at the $10 \%$ level, **Significant at the $5 \%$ level, ***Significant at the $1 \%$ level.

\subsection{Panel Causality Results}

The Granger causality results between banking sector development and economic growth are presented in Table 7. The results of the Granger causality tests are consistent with the cointegration results based on the idea that if two or more variables are cointegrated, then at least one-way causality must exist in the system to take it toward equilibrium. In Table 7, the Granger causality tests show that there is an evidence of one-way causality from economic growth to banking sector development in the short-run and long-run. Empirical results show long-run Granger causality running from economic growth to BA, LIQ, and PC, as the error correction terms are significant at the $1 \%$ level, $10 \%$, and $1 \%$ level respectively. Furthermore, there is no evidence that LIQ and BA have an impact on economic growth in the short-run. However, there is short-run causality running from PC to economic growth which indicates that there is a bi-directional relationship between PC and economic growth. The evidence of one-way causality running from economic growth to financial development gives support to the demand-pulling phenomenon.

Table 6. Impact of financial development on economic growth

\begin{tabular}{|c|c|c|c|c|c|c|c|}
\hline Independent Variables & Benchmark & 1 & 2 & 3 & 4 & 5 & 6 \\
\hline \multirow[t]{2}{*}{ GOV } & -0.080 & -0.058 & -0.132 & -0.128 & -0.108 & -0.132 & -0.117 \\
\hline & $(-2.4)^{* *}$ & $(-1.75)^{* *}$ & $(-3.52)^{* *}$ & $(-3.82)^{* *}$ & $(-3.18)^{* *}$ & $(-3.54)^{* *}$ & $(-3.64)^{* *}$ \\
\hline \multirow[t]{2}{*}{$\mathrm{SCH}$} & 0.036 & 0.033 & 0.035 & 0.046 & 0.043 & 0.035 & 0.038 \\
\hline & $(2.52)^{* *}$ & $(2.88)^{* *}$ & $(2.14)^{* *}$ & $(2.97)^{* *}$ & $(2.81)^{* *}$ & $(2.11)^{* *}$ & $(2.61)^{* *}$ \\
\hline \multirow[t]{2}{*}{ OP } & 0.047 & 0.040 & 0.098 & 0.136 & 0.102 & 0.085 & 0.098 \\
\hline & $(3.05)^{* * *}$ & $(2.80)^{* * *}$ & $(3.53)^{* * *}$ & $(3.54)^{* * *}$ & $(3.53)^{* * *}$ & $(3.33)^{* * *}$ & $(3.53)^{* * *}$ \\
\hline \multirow[t]{2}{*}{ IR } & -0.067 & -0.051 & -0.073 & -0.098 & -0.085 & -0.078 & -0.086 \\
\hline & $(-2.30)^{* *}$ & $(-1.65)^{*}$ & $(-2.52)^{* *}$ & $(-3.60)^{* *}$ & $(-2.95)^{* *}$ & $(-2.67)^{* *}$ & $(-3.09)^{* *}$ \\
\hline \multirow[t]{2}{*}{$\mathrm{BA}$} & & -0.153 & -1.256 & -0.845 & -1.342 & -1.323 & -0.987 \\
\hline & & $(-1.34)$ & $(-0.76)$ & $(-0.52)$ & $(-0.94)$ & $(-0.74)$ & $(-0.56)$ \\
\hline \multirow[t]{2}{*}{ LIQ } & & & 0.030 & 0.028 & 0.034 & 0.026 & 0.033 \\
\hline & & & $(3.61)^{* *}$ & $(3.27)^{* *}$ & $(4.09)^{* *}$ & $(2.73)^{* *}$ & $(3.88)^{* *}$ \\
\hline
\end{tabular}




\begin{tabular}{|c|c|c|c|c|c|c|c|}
\hline $\mathrm{PC}$ & & & & $\begin{array}{c}0.076 \\
(2.26)^{* *}\end{array}$ & $\begin{array}{c}0.131 \\
(3.80)^{* *}\end{array}$ & $\begin{array}{c}0.124 \\
(3.97)^{* *}\end{array}$ & $\begin{array}{c}0.118 \\
(3.25)^{* *}\end{array}$ \\
\hline $\mathrm{SMC}$ & & & & & $\begin{array}{c}0.018 \\
(4.89)^{* *}\end{array}$ & $\begin{array}{c}0.016 \\
(4.04)^{* *}\end{array}$ & $\begin{array}{c}0.006 \\
(1.80)^{*}\end{array}$ \\
\hline VT & & & & & & $\begin{array}{c}0.080 \\
(3.53)^{* *}\end{array}$ & $\begin{array}{c}0.009 \\
(3.04)^{* *}\end{array}$ \\
\hline TR & & & & & & $\begin{array}{c}0.017 \\
(5.85)^{* *}\end{array}$ & $\begin{array}{c}0.018 \\
(5.75)^{* *}\end{array}$ \\
\hline Adj R-squared & 0.139 & 0.154 & 0.127 & 0.125 & 0.138 & 0.124 & 0.151 \\
\hline Durbin-Watson & 2.130 & 1.982 & 1.782 & 2.038 & 2.003 & 1.905 & 2.118 \\
\hline $\begin{array}{l}\text { Hausman test } \\
p \text {-value }\end{array}$ & $\begin{array}{c}12.66^{* * *} \\
(0.03)\end{array}$ & $\begin{array}{c}15.74 * * \\
(0.01)\end{array}$ & $\begin{array}{l}8.140 \\
(0.15)\end{array}$ & $\begin{array}{c}12.27 * * \\
(0.03)\end{array}$ & $\begin{array}{l}7.820 \\
(0.17)\end{array}$ & $\begin{array}{c}11.76^{* *} \\
(0.04)\end{array}$ & $\begin{array}{c}13.47 * * \\
(0.02)\end{array}$ \\
\hline
\end{tabular}

Note. Values in parentheses are t-statistics. *Significant at the $10 \%$ level, **Significant at the $5 \%$ level, ***Significant at the $1 \%$ level.

Overall, the results of the causality and panel cointegration tests suggest that there is evidence of long-run linkages between banking development and economic growth in Latin America. However, it seems that of banking development may not be a crucial role in the economic development process in the region. The main reasons behind this result could be the numerous financial crises the Latin American countries have experienced, government intervention in that sector through the 1970s and 1980s to finance their budget deficits with borrowing and implicit taxation, and tighter credit constraints (Note 6).

Table 8 shows the causality results between stock market development and economic growth. The results show bi-directional relationships between the three indicators and economic growth. The null hypotheses that SMC, VT, and TR do not cause economic growth are rejected in both the short-run and the long-run. The results also show the presence of bi-directional causality relationships between stock market development and economic growth in Latin America both in short-run and long-run. The ECTs in Table 8 indicate that there exist mechanisms in correcting the disequilibrium between stock market development indicators and economic growth. They have the right sign and are significant even though some are at $10 \%$. The significant negative sign of the ECT indeed supports the cointegration relationship between stock market development and economic growth.

Table 7. Panel granger causality tests (banking development indicators)

\begin{tabular}{lcc}
\hline Null Hypothesis & Short run & Long run \\
\hline & $F$-statistics $(p$-value $)$ & $E C T_{t-1}(t$-statistics $)$ \\
BA does not Granger cause EG & 1.1969 & -0.06496 \\
& $(0.3140)$ & $(-0.6705)$ \\
EG does not Granger cause BA & $3.09302^{*}$ & $-0.60138^{* * *}$ \\
& $(0.06462)$ & $(-4.52926)$ \\
LIQ does not Granger cause EG & 2.45188 & -0.31818 \\
& $(0.10833)$ & $(-1.57711)$ \\
EG does not Granger cause LIQ & $4.54822^{* *}$ & $-0.2585^{*}$ \\
& $(0.02166)$ & $(-1.9103)$ \\
PC does not Granger cause EG & $2.069^{*}$ & $-0.6819^{* * *}$ \\
& $(0.0869)$ & $(-2.8880)$ \\
EG does not Granger cause PC & $4.2438^{* * *}$ & $-0.662^{* * *}$ \\
& $(0.0027)$ & $(-3.3417)$ \\
\hline
\end{tabular}

Note. Parenthesized values are the probability of rejection the null hypothesis of Granger non-causality. *Significant at the $10 \%$ level, **Significant at the $5 \%$ level, $* * *$ Significant at the $1 \%$ level.

Table 8. Panel granger causality tests (stock market development indicators)

\begin{tabular}{lcc}
\hline Null Hypothesis & Short run & Long run \\
\hline & $F$-statistics $(p$-value $)$ & $E C T_{t-1}(t$-statistics $)$ \\
SMC does not Granger cause EG & $3.4157^{* *}$ & $-0.1975^{*}$ \\
& $(0.0020)$ & $(-2.0432)$ \\
EG does not Granger cause SMC & $2.4463^{*}$ & $-0.3512^{*}$ \\
\hline
\end{tabular}




\begin{tabular}{lcc}
\hline & $(0.0678)$ & $(-1.8054)$ \\
VT does not Granger cause EG & $4.2603 * * *$ & $-0.1408^{* * *}$ \\
EG does not Granger cause VT & $(0.0064)$ & $(-2.9027)$ \\
& $2.4966^{* * *}$ & $-0.3855^{* * *}$ \\
TR does not Granger cause EG & $(0.0077)$ & $(-4.428)$ \\
& $4.8712^{* * *}$ & $-0.3712^{* * *}$ \\
EG does not Granger cause TR & $(0.0032)$ & $(-5.188)$ \\
& $3.4157 * *$ & $-0.4613 *$ \\
\hline
\end{tabular}

Note. Parenthesized values are the probability of rejection the null hypothesis of Granger non-causality. *Significant at the $10 \%$ level, ** Significant at the $5 \%$ level, ***Significant at the $1 \%$ level.

\section{Conclusions and Policy Implications}

This paper examines the relationship between financial development and economic growth for 14 Latin American countries from 1978 to 2011 using panel data methods and applying Granger causality tests within a framework of a panel cointegration and error correction model. The empirical findings and their policy implications can be summarized as follows. First, our findings suggest that the causal relationship between financial development and economic growth is sensitive to financial development measures used. Second, when banking sector development indicators are used as measures of financial development, the empirical results show that there is evidence of uni-directional causality from economic growth to banking sector development. Finally, the findings indicate a strong bi-directional causality between stock market development and economic growth when stock market development indicators are used as proxies for financial development.

The study, therefore, recommends that the real sector of Latin American economies should be further developed in order to achieve higher levels of banking sector development. Policymakers in Latin American countries must undertake essential measures to strengthen bank supervision and regulation. These measures include restricting government involvement in the banking sector systems, rehabilitating or resolving weak or failed banks, and enhancing competition. Furthermore, policymakers should remove any regulatory and legal barriers to stock market development. Finally, policies that foster macroeconomic stability, increased openness, investment in human capital and productive government spending, and therefore improve economic growth, would also have an important effect on economic growth in the long-run.

\section{References}

Abramovitz, M. (1986). Catching up, forging ahead, and falling behind. Journal of Economic History, 46, 385406. http://dx.doi.org/10.1017/S0022050700046209

Al-Yousif. (2002). Financial development and economic growth. Another look at the evidence from developing countries. Review of Financial Economics, 11, 131-150.

Andres, J., Hernando, I., \& Lopez-Salido, J. (1999). The role of the financial system in the growth-inflation link: The OECD experience. Banco de Espana, Working Paper.

Apergis, N., Filippidi, I., \& Economidou, C. (2007). Financial Deepening and Economic Growth Linkages: A Panel Data Analysis. Review of World Economics, 143, 179-198. http://dx.doi.org/10.1007/s10290-007-0102-3

Aslan, A. (2008). Financial Development and Economic Growth: A Panel Cointegration Analysis of Middle East Countries. The Empirical Economics Letters, 7, 681-691.

Barro, R. J. (1996). Inflation and Growth. Federal Reserve Bank of St. Louis Review, (May/June), 153-169.

Barro, R. J., \& Sala-i-Martin, X. (1995). Economic Growth. Boston, Mass: Mc-Graw Hill.

Beck, T., \& Levine, R. (2004). Stock markets, banks, and growth: Panel evidence. Journal of Banking and Finance, 28, 423-442. http://dx.doi.org/10.1016/S0378-4266(02)00408-9

Boubakari, A. A., \& Jin, D. (2010). The Role of Stock Market Development in Economic Growth: Evidence from Some Euro next Countries. International Journal of Financial Research, 1, 14-20. http://dx.doi.org/10.5430/ijfr.v1n1p14

Boyd, J., Levine, R., \& Smith, B. (2001). The impact of inflation on financial sector performance. Journal of Monetary Economics, 47, 221-248. http://dx.doi.org/10.1016/S0304-3932(01)00049-6 
Braun, M., \& Hausmann, R. (2002). Financial Development and Credit Crunches: Latin America and the World. In J. Vial \& P. K. Cornelius (Eds.), Latin American Competitiveness Report. New York: Oxford University Press.

Bruno, M., \& Easterly, W. (1998). Inflation crises and long-run growth. Journal of Monetary Economics, 41, 326. http://dx.doi.org/10.1016/S0304-3932(97)00063-9

Claessens, S., \& Laeven, L. (2003). Financial Development, Property Rights and Growth. Journal of Finance, 58, 2401-2436. http://dx.doi.org/10.1046/j.1540-6261.2003.00610.x

Darrat, A. F. (1999). Are financial deepening and economic growth causally related? Another look at the evidence. International Economic Journal, 13, 19-35.

Deb, S. G., \& Mukherjee, J. (2008). Does Stock Market Development Cause Economic Growth? A Time Series Analysis for Indian Economy. International Research Journal of Finance and Economics, 21, 142-149.

Demetriades, P., \& Hussein, K. (1996). Does financial development cause economic growth? Time series evidence from 16 countries. Journal of Development Economics, 51, 387-411. http://dx.doi.org/10.1016/S0304-3878(96)00421-X

Easterly, W., \& Rebelo, S. (1993). Fiscal Policy and Growth: An Empirical Investigation. Journal of Monetary Economics, 32, 417-458. http://dx.doi.org/10.1016/0304-3932(93)90025-B

Engle, R. F., \& Granger, C. W. J. (1987). Cointegration and Error Correction: Representation, Estimation and Testing. Econometrica, 55, 251-276. http://dx.doi.org/10.2307/1913236

Fischer, S. (1993). The Role of Macroeconomic Factors in Growth. Journal of Monetary Economics, 32, 485512. http://dx.doi.org/10.1016/0304-3932(93)90027-D

Garcia, V., \& Liu, L. (1999). Macroeconomic Determinants of Stock Market Development. Journal of Applied Economics, 1, 29-59.

Granger, C. W. J. (1980). Long memory relationships and the aggregation of dynamic models. Journal of Econometrics, 14, 227-238. http://dx.doi.org/10.1016/0304-4076(80)90092-5

Hondroyiannis, G., Lolos, S., \& Papapetrou, E. (2004). Financial Markets and Economic Growth in GREECE, 1986-1999. Working Paper, No. 17.

Ikikii, M. S., \& Nzomoi, N. J. (2013). An Analysis of the Effects of Stock Market Development on Economic Growth in Kenya. International Journal of Economics and Finance, 5, 145-151. http://dx.doi.org/10.5539/ijef.v5n11p145

Im, K. S., Pesaran, M. H., \& Shin, Y. (2003). Testing for unit roots in heterogeneous panels. Journal of Econometrics, 115, 53-74. http://dx.doi.org/10.1016/S0304-4076(03)00092-7

Johansen, S. (1988). Statistical Analysis of Cointegration Vectors. Journal of Dynamics and Control, 12, 231254. http://dx.doi.org/10.1016/0165-1889(88)90041-3

King, R., \& Levine, R. (1993). Finance and Growth: Schumpeter Might Be Right. Quarterly Journal of Economics, 108, 717-738. http://dx.doi.org/10.2307/2118406

Levine, R. (1997). Financial Development and Economic Growth: Views and Agenda. Journal of Economic Literature, 35, 688-726.

Levine, R. (2002). Bank-based or market-based financial systems: Which is better? Journal of Financial Intermediation, 11, 398-428. http://dx.doi.org/10.1006/jfin.2002.0341

Levine, R., \& Zervos, S. (1998). Stock markets, banks, and economic growth. American Economic Review, 3, 537-558.

Levine, R., Loayza, N., \& Thorsten, B. (2000). Financial intermediation and growth: causality and causes. Journal of Monetary Economics, 46, 31-77. http://dx.doi.org/10.1016/S0304-3932(00)00017-9

Lucas, Jr. R. E. (1988). On the mechanics of economic development. Journal of Monetary Economics, 22 , 3-42. http://dx.doi.org/10.1016/0304-3932(88)90168-7

Luintel, K. B., \& Khan, M. (1999). A Quantitative Reassessment of the Finance-Growth Nexus: Evidence from a Mult ivariate VAR. Journal of Development Economics, 60, 381-405. http://dx.doi.org/10.1016/S0304-3878(99)00045-0

Moschos, D. (1989). Export expansion, growth and the level of economic development. Journal of Development 
Economies, 30, 93-102. http://dx.doi.org/10.1016/0304-3878(89)90052-7

Okoye, O. V., \& Nwisienyi, J. K. (2013). The capital market contributions towards economic growth and development; the Nigerian experience. Global Advanced Research Journal of Management and Business Studies, 2, 120-125.

Padhan, P. C. (2007). The Nexus between Stock Market and Economic Activity: An Empirical Analysis for India, International Journal of Social Economics, 34, 741-753. http://dx.doi.org/10.1108/03068290710816874

Pedroni, P. (1999). Critical Values for Cointegration Tests in Heterogeneous Panels with Multiple Regressors. Oxford Bulletin of Economics and Statistics, 61, 653-678. http://dx.doi.org/10.1111/1468-0084.61.s1.14

Robinson, J. (1952). The rate of interest and other essays. London: Macmillan.

Rousseau, P., \& Wachtel, P. (2000). Equity Markets and Growth: Cross Country Evidence on Timing and Outcomes, 1980-1995. Journal of Banking and Finance, 24, 1933-1957. http://dx.doi.org/10.1016/S0378-4266(99)00123-5

Rousseau, P., \& Wachtel, P. (2002). Inflation thresholds and the finance-growth nexus. Journal of International Money and Finance, 21, 777-793. http://dx.doi.org/10.1016/S0261-5606(02)00022-0

Shan, J. Z., Sun, F., \& Morris, A. (2001). Financial development and economic growth. Review of International Economics, 9, 443-454. http://dx.doi.org/10.1111/1467-9396.00291

Tang, D. (2006). The effect of financial development on economic growth: evidence from the APEC countries, 1981-2000. Applied Economics, 38, 1889-1904. http://dx.doi.org/10.1080/00036840500427239

Tyler, W. B. (1981). Growth and Export Expansion in Developing Countries. Journal of Development Economics, 9, 121-130. http://dx.doi.org/10.1016/0304-3878(81)90007-9

World Bank. (2009). World Development Indicators 2008. Washington, D.C.: World Bank. CD-ROM.

\section{Notes}

Note 1. See Levine (1997) for surveys of the theoretical literature.

Note 2. The Latin American countries in the sample are Argentina, Bolivia, Brazil, Chile, Colombia, Costa Rica, Ecuador, El Salvador, Guatemala, Mexico, Peru, Paraguay, Uruguay, and Venezuela. The choice of the sample countries is dictated by the availability of long-run time series data.

Note 3. See Pedroni (1999) for details and mathematical representations of the tests.

Note 4. The lag length used to compute the IPS panel unit root test statistics is based on Akaike Information Criteria (AIC).

Note 5. See King and Levine (1993), and Levine (1997).

Note 6. Braun \& Hausmann (2002) note that "in many Latin American countries, the quality of bank capital is low, asset classifications are not sufficiently conservative, and consolidation of off-shore activities remains problematic. As a result, some banking systems in the region remain underdeveloped."

\section{Copyrights}

Copyright for this article is retained by the author(s), with first publication rights granted to the journal.

This is an open-access article distributed under the terms and conditions of the Creative Commons Attribution license (http://creativecommons.org/licenses/by/3.0/). 